\title{
Financing of Regional and Local Development by the Territorial Self-government Units in Poland Within the EU Cohesion Policies
}

\author{
Magdalena KOGUT-JAWORSKA \\ University of Szczecin, Szczecin, Poland \\ magdalena.kogut@wzieu.pl
}

\begin{abstract}
The self-governmental sector is one of the most important ones in realisation of public assignments and missions. The territorial self-government in Poland is perceived as the most important investor and service supplier. Territorial self-government units perform own tasks with the aim of meeting common needs of self-governmental communities. Realisation of these tasks requires adequate infrastructure, equipment and financing. In this context, particular importance should be given to financing ventures contributing into social and economic development in regions and local communities. The aim of this paper is analysis of policies implemented in Poland so far, the policies which are set in the framework of the cohesion policy restricted to institution dimension of the regional and local development.
\end{abstract}

Keywords: Local Development, Regional Finance, Cohesion Policy.

\section{Introduction}

The self-governmental sector is one of the most important ones in realisation of public assignments and missions. The territorial self-government in Poland is perceived as the most important investor and service supplier [7]. Territorial self-government units perform own tasks with the aim of meeting common needs of self-governmental communities. Realisation of these tasks requires adequate infrastructure, equipment and financing. In this context, particular importance should be given to financing ventures contributing into social and economic development in regions and local communities.

Cohesion policy, also known as regional policy is one of the European Union and aims at equaling of work and living standards of all citizens in the European Community. The attempt to close the gap in social and economic development of all regions and local areas should be achieved through proper utilization of existing means, with application of supporting instruments directed at territorial selfgovernment units which are interested in getting support for the pro-growth processes.

The aim of this paper (chapter) is analysis of policies implemented in Poland so far, the policies which are set in the framework of the cohesion policy restricted to institution dimension of the regional and local development Analysis of the literature 
and of other data sources lead to the conclusion that the systemic solutions concerning absorption of the EU funds in Poland support activities of the territorial selfgovernment units as far as financing of social and economic development is concerned.

\section{Regional and local development and self- governmental sources of its financing - basic definitions and their interpretations}

Development is a long - lasting process of changes directed at something or somebody. Another interpretation of this notion indicates that it is a process of changes throughout which an object evolves into more complex and more refined forms. Development defined as above is quite near to the notion of progress which, in turn, is closely connected to such terms as progression improvement, amelioration or advancement in time. Both, development and progress are related to some processes which can be, more or less, connected with time and space. Taking into consideration place of origin of the development processes and their character, as well as conditions and factors shaping or influencing the phenomena in question, development can be defined as global, regional or local.

Global development can also be defined differently. B. Domański indicates that: "when it is related to regions, the concepts of economic or socio-economic development are mostly applied. The concepts are perceived as, firstly, immanent processes, and secondly as international actions of authorities" [3]. Another definition says that regional development is "a steady increase of living standard of the population and growth of economic potential in a big territorial unit, which includes i.a.: economic structure, natural environment and living standards, as well as urban and infrastructural development." [6].

Local development is defined differently in the literature referring to the subject. Firstly, local development is a process, not a state, so the effects of the development can be expected over a long period. Secondly, local development means purposive and mindful actions. Thirdly, the subject of local development are local authorities, inhabitants and entities which function in the local market. Another part of the definition stresses that local development refers to a smaller area (e.g. a local community or a town) than the regional development, and the local authorities are, in the first place, responsible for local development. Another feature in the defining description say about rational utilization of resources by the entities.

The self-governmental sector is one of the crucial components contributing to realisation of public aims in Poland. The territorial self-government is perceived as the most important service supplier and investor [7]. Territorial self-government units, through initialing social and economic development on their territories, fulfill own tasks, aiming at meeting the needs of their communities. In particular, the territorial 
self-government units realise goals for common good whose aim is to cater for the needs of the community through supplies of services available for everybody.

The system for self-government financing which functions in Poland and contributes into the local and regional development is shaped by many elements. In particular, it is conditioned by the existing structure of administrative division of the country, differences in development of the regions, dominating political concepts and by the current situation in public finance sector, [8]. Financial resources being at the disposal of self-governments decide about the power and level of self-dependence of local decision makers. The resources confirm stable economic situation and have influence over the potential for development in communes, countries and regions (voivodeships).

A system of self-governmental finances should meet numerous conditions described in the theory and present in the law, i.a., it should be transparent, stable and corresponding with the needs within the framework for financing of the public tasks commended to the self-government [12]. The question of budget revenues and their predictability for the local self-government budget is of particular importance as well as the legal power to decide about methods and places of allocation of the local revenues, as well as a necessity to channel some means for particular objectives.

The most important categories describing sources of self-government financing in Poland can be presented in the following way [11]:

- own income - appertained to the self-government totally and termlessly, connected with the local economic base and for which the local self-government is free to set levels for the revenues. The most common own-source revenues of the self-government include: local taxes and fees, fees for services supplied by the self-government, property income (dividends and other capital income, leasing, sales),

- transfers from the central budget and from other self-governments or from other (non-budget) sources, and in particular:

- subsidies - transfers of general character, they are not dedicated to particular objectives and self-governments decide about their application,

- grants - transfers having a strictly attached goal which cannot be changed without a consent from the donor,

- self-government's participation in sharing of revenues from some taxes between different levels of self-governmental administration and the central budget - in particular, the revenues from the personal income tax (PIT) and from the company income tax (CIT).

- returnable means - are part of a separate category of revenue and they technically cover deficit of the budget. The category includes bank credit, loans from other sources, as well as means from issuing municipal bonds.

A broader classification of financing sources for the territorial self-government in Poland takes into consideration the following division [4]: 
- Public funds supporting realisation of tasks for territorial self-government units (including own income and budget transfers for self-government units), i. a.: local taxes and fees, income tax from activities of the self-government, subservient and subordinate units, property income, other own income, tax revenue collectible for self-government units according to the regulations, grants, subsidies, funds from the European Union budget.

- Private funds supporting realisation of the territorial self-government objectives, including: bonds or other credit instruments (bank bills and papers), loans, liabilities, leasing and other similar contracts.

- Hybrid financing and the remaining financial methods for realisation of objectives set for self-governments, i.a.: public-private partnership, project finance, venture capital, securitization, debt conversion and guarantees

\section{Assessment of UE funds participation in the self-government expenditures - basic classification and data analysis}

When analysing the question of expenditures made by territorial self-government units aimed at supporting regional and local development, it is important to refer to the structure of the expenditure which allows to assess the level of participation of self-governmental financial means in the total amount spent on investment. The crucial importance should be given to division of the expenditure- into the current and property ones. Property expenditures, in the first place on investment, have a prodevelopment character - they build infrastructure, create jobs, etc. However, current expenditures are in fact, connected with realisation of tasks assigned to selfgovernment units by law. It must be stressed that the amount of property expenditure depends, above all, on the level of own income and possibilities to cover by it the liabilities resulting from investment [9].

Table 1. Financial data in total (mln of PLN) - all territorial self-government units. Source: own compilation based on [13].

\begin{tabular}{|c|c|c|c|c|c|c|c|}
\hline & & 2012 & 2013 & 2014 & 2015 & 2016 & 2017 \\
\hline 1 & $\begin{array}{r}\text { Current income } \\
\text { Current }\end{array}$ & 156468 & 163169 & 171722 & 176067 & 200491 & 202596 \\
\hline 2 & expenditure & 144842 & 148832 & 155404 & 157839 & 180162 & 189300 \\
\hline 3 & Operational surplus & 11672 & 14337 & 16318 & 18228 & 20329 & 13297 \\
\hline 4 & $\begin{array}{r}\text { Property income } \\
\text { Property }\end{array}$ & 20945 & 20290 & 22616 & 22952 & 12943 & 21178 \\
\hline 5 & expenditure & 35617 & 35007 & 41350 & 38576 & 25583 & 45926 \\
\hline 6 & Asset balance & -14673 & -14718 & -18735 & -15624 & -12640 & -24747 \\
\hline 7 & Total income & 177413 & 183458 & 194337 & 199019 & 213434 & 223775 \\
\hline 8 & Total Expenditure & 180459 & 183839 & 196754 & 196415 & 205745 & 235225 \\
\hline 9 & Surplus/deficit & -3046 & -380 & -2417 & 2604 & 7689 & -11450 \\
\hline
\end{tabular}




\begin{tabular}{|c|c|c|c|c|c|c|c|}
\hline 10 & Revenue & 24200 & 24062 & 22894 & 20258 & 13813 & 20377 \\
\hline a & New debt & 12649 & 12959 & 11246 & 8096 & 5400 & 14379 \\
\hline b & Other revenue & 11551 & 11103 & 11647 & 12162 & 8413 & 5998 \\
\hline 11 & Expenditure & 12146 & 13753 & 9304 & 11221 & 7923 & 8929 \\
\hline $\mathrm{a}$ & Debt repayment & 10104 & 11839 & 9028 & 11003 & 6815 & 7996 \\
\hline b & Other expenditure & 2041 & 1914 & 277 & 218 & 1109 & 934 \\
\hline 12 & $\begin{array}{r}\text { Financing } \\
\text { Budget balance }\end{array}$ & 12054 & 10309 & 13589 & 9037 & 5890 & 11448 \\
\hline 13 & total & 9008 & 9928 & 11172 & 11640 & 13579 & -2 \\
\hline
\end{tabular}

It can be observed that, over the researched period, average investment expenditures were fluctuating, showing a decreasing tendency. Such a situation was a result of, on one hand, intensification of investment activities resulting from accumulation of the EU projects in the implementation phase within the perspective 2007-2013. On the other hand, over that period, there appeared economic showdown and the European crisis which limited possibilities of public sector units, including local communities. It also needs to be stressed that, in the period when the biggest investment projects were implemented (2011-2012), differences between self-governments, as far as the implementation was concerned, were the largest.

Taking in consideration the value of accumulated investment, on average - the biggest investment projects were implemented by city boroughs followed by country boroughs and the smallest projects were realized by the mixed city-country boroughs. Such an outcome can be perceived as very obvious, considering the scale of needs of city communes. Equally, the latter is a group of communes featuring the largest diversity of the investment implemented [10]. Moreover, it can be added, that the most important item among the expenditures of the self-government units is the outlay on education which makes approx. $30 \%$ of total expenditures in the period in question. The second largest category of expenditures are the ones connected to transport and communication, approx. $20 \%$ of the total, followed by those on social welfare - about $15 \%$, and lastly, by the outlays on public administration and municipal utilities. The above mentioned five categories of expenditure have the largest influence on budgets of the territorial self-government units.

Over the last years, the units of territorial self-government in Poland have been implementing a considerable amount of pro-growth projects. Opportunities of receiving financial aid from the European Union budget have forced some actions to be taken by the self-government units in order to secure their own financial input, which was necessary to obtain the EU financing. This, in turn, resulted in increase of liabilities within the self-government sector. At present, self-governments have begun the second and probably the last development plan of such large dimension. This will be connected with a considerable increase of burden in their budgets and, in consequence, with a high level of debt servicing in the years to come. Data from multi-annual projections for self-government units confirm considerable differentiation of operational results of particular self-government units, which indicates a necessity of individual approach towards assessment of financial situation in those units. Nevertheless, it can be expected that the growing amount of repayable 
financing which even now burdens the self-governments considerably, will result in investment decrease in the nearest future.

The rule of financial self-dependence is mandatory for shaping the expenditures. The rule evinces itself in the authority given to the administrative bodies in order to establish a hierarchy of needs and ways of financing, after having considered a necessity to realise mandatory expenditures. Territorial self-government units have a right to decide about a division of financial means into current and investment tasks. Between 2010 and 2014 there appeared incremental increase of the EU financing, for the both, current and property expenditure. Due to the new financial perspective starting after 2014, there can be noticed a drop in the amount of financial aid in 2015. Higher level of financing for ventures focused on property tasks is planned by the self-government units for the years to come, i.e. after 2017. As said above, it applies to property expenditures. The reasons for such shifts in absorption of the EU funds can be found in the change of long - term financial framework.

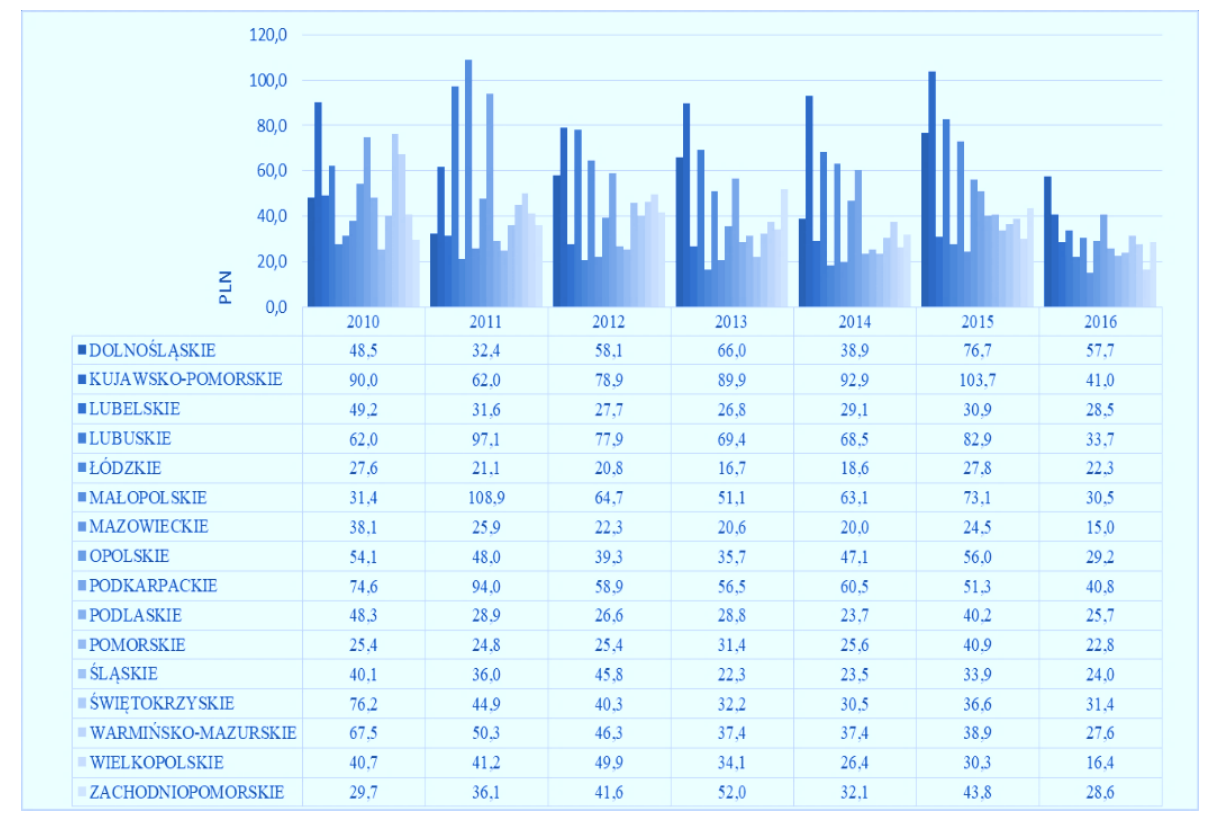

Fig. 1. Revenue and expenditure of local self-government entities budgets. Funds from EU to finance programs and projects EU per capita. Source: own compilation based on [14].

Territorial self-government units in Poland were on a growth path when a short-term down turn took place. In that period, the self-government sector in Poland was strongly supported by the absorption of the structural funds from the European Union. In the oncoming period the self-governments will be confronted with new development opportunities for infrastructure and investment, although at the start there might be some difficulties in fund absorption within the new perspective. It is forecast that further implementation of investment plans based to a greater extent on debt instruments. However, presently, the level of self-governments' indebtedness is 
considerably higher and the absorption of the financial aid can prove much more difficult and burdened with definitely higher cost of borrowing.

\section{Cohesion policies and the European funds in financing of regional development in Poland - assessment of the current situation}

European Union Funds bring opportunities for territorial self-governments to implement pro-growth ventures, both infrastructural and those connected with development of local communities [1, 2]. Participation of the European funds in budget revenues of territorial self-government units is a measure of local authority engagement in sourcing of external financing. A share of the EU funds in territorial self-government revenues was steadily increasing in the financial perspective 20072013. However, since 2014, the participation of the EU financial aid in ventures run by territorial self-government units has been smaller, which might be a consequence of going through a preparatory stage for the new financial perspective before actual implementation of the perspective (see figure 2).

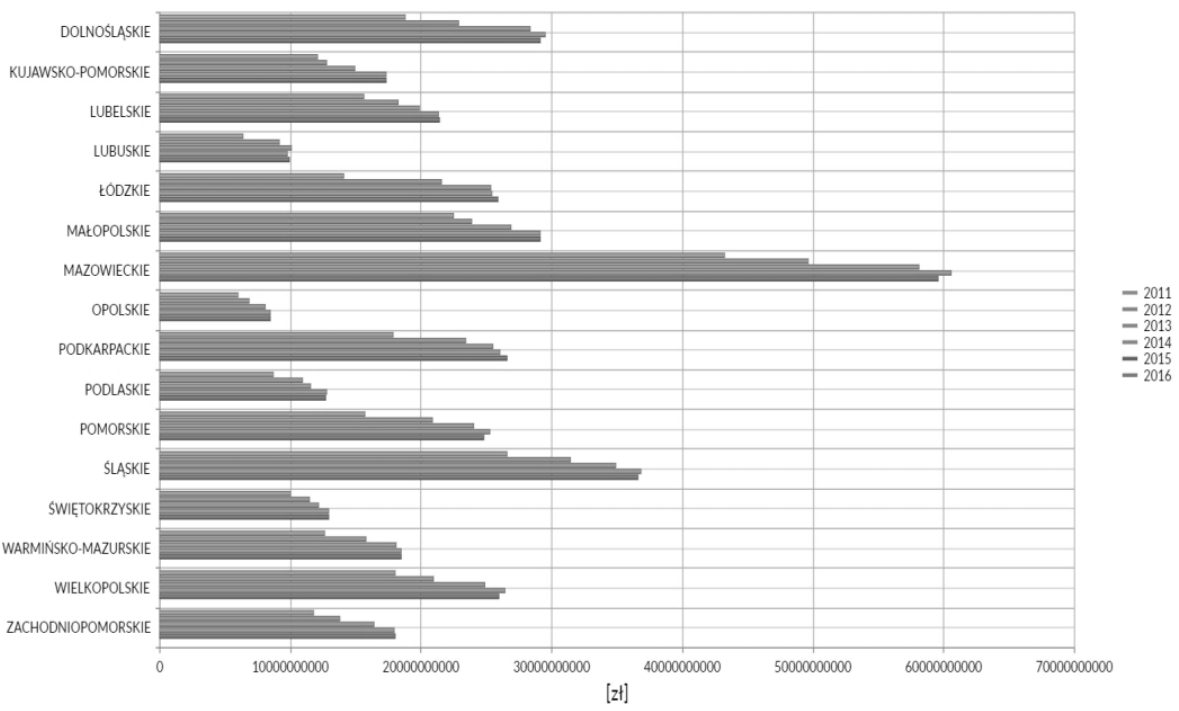

Fig. 2. Total value of the projects according to operational programmes and financing sources, NSRO 2017-2013. Source: own compilation based on [14].

In Poland, the European Union Funds in the new financial perspective 2014-2020 are implemented at the two levels - central and regional one. At the central level, there are European Territorial Cooperation Programmes and 8 national programmes financed by the European Fund for Regional Development (the EFRR), the European Social Fund (the EFS), the Cohesion Fund (the FS), as well as by the European 
Agricultural Fund for Rural Areas Development (the EFRROW) and by the European Maritime and Fishing Industry Fund (the EFMR). When analysing the regional level, there are 16 two-found regional operational programmes planned for realization from the European Social Fund - 1 for Mazoria region and 15 for the remaining regions. The implementation of the programmes by the territorial self-government units for 2014-2020 is presented in the table below (see table 2).

Table 2. Implementation of the programmes for 2014-2020 contracts according to the legal form of the beneficiary - Self-Governments Units (as for 31.08.2017). Source: based on [15].

\begin{tabular}{|c|c|c|c|}
\hline Operational Program & Total value & $\begin{array}{l}\text { Expenditure } \\
\text { qualified by } \\
\text { the rules }\end{array}$ & UE input \\
\hline $\begin{array}{l}\text { Operational Programme } \\
\text { Infrastructure and Environment } \\
2014-2020\end{array}$ & 13956895538 & 11445660818 & 9132145290 \\
\hline $\begin{array}{l}\text { Operational Programme } \\
\text { Development of Eastern Poland } \\
2014-2020\end{array}$ & 3127774773 & 2821554935 & 2352919059 \\
\hline $\begin{array}{l}\text { Operational Program Knowledge } \\
\text { Development Education 2014- } \\
2020\end{array}$ & 3365336401 & 3365336401 & 2983037213 \\
\hline $\begin{array}{l}\text { Regional Programme for } \\
\text { Lubuskie Voivodeship 2014- } \\
2020\end{array}$ & 1234282870 & 1150876446 & 949006583 \\
\hline $\begin{array}{l}\text { Regional Programme for } \\
\text { Dolnośląskie Voivodeship 2014- } \\
2020\end{array}$ & 2331426307 & 1998814124 & 1602780301 \\
\hline $\begin{array}{l}\text { Regional Programme for } \\
\text { Kujawsko-Pomorskie } \\
\text { Voivodeship 2014-2020 }\end{array}$ & 1169059207 & 1119648560 & 897167550 \\
\hline $\begin{array}{l}\text { Regional Programme for } \\
\text { Lubelskie Voivodeship 2014- } \\
2020\end{array}$ & 2229015787 & 2058491548 & 1721221700 \\
\hline $\begin{array}{l}\text { Regional Programme for Łódzkie } \\
\text { Voivodeship 2014-2020 }\end{array}$ & 3100724948 & 2516038793 & 1967965437 \\
\hline $\begin{array}{l}\text { Regional Programme for } \\
\text { Małopolskie Voivodeship 2014- } \\
2020\end{array}$ & 2565785269 & 2374224588 & 1845825086 \\
\hline $\begin{array}{l}\text { Regional Programme for } \\
\text { Mazowieckie 2014-2020 }\end{array}$ & 2266933037 & 2112006049 & 1595018308 \\
\hline $\begin{array}{l}\text { Regional Programme for } \\
\text { Opolskie Voivodeship 2014- } \\
2020\end{array}$ & 1147851120 & 1108017191 & 926926505 \\
\hline $\begin{array}{l}\text { Regional Programme for } \\
\text { Podkarpackie Voivodeship 2014- } \\
2020\end{array}$ & 2301088773 & 2014213585 & 1633384439 \\
\hline
\end{tabular}


Regional Programme for Podlaskie Voivodeship 2014

2020

Regional Programme for

Pomorskie Voivodeship 2014-

$3963190317 \quad 3686411425 \quad 2805347270$

2020

Regional Programme for Śląskie

Voivodeship 2014-2020

Regional Programme for

Świętokrzyskie Voivodeship

2014-2020

Regional Programme for

Warmińsko-Mazurskie

Voivodeship 2014-2020

Regional Programme for

Zachodniopomorskie 2014-2020

Regional Programme for

Wielkopolska 2014-2020

$\begin{array}{crc}3432252195 & 3067044933 & 2506121913 \\ 595860113 & 534766901 & 440097092 \\ 949455437 & 897167164 & 716937820 \\ 1327253286 & 1197198902 & 989779262 \\ 3263616443 & 3025959467 & 2460855888\end{array}$

In the current years 2014-2020, from all aid available from the EU budget (aprox. 82,5 bln PLN) much more means have been transferred to the regional level. It is estimated that the regional self-government has at its disposal approx. $40 \%$ of the cohesion policy aid, which is about $15 \%$ more than in the years 2007-2013. It has been concluded that territorial self-government units are the greatest beneficiary of the aid. It is both a chance and a challenge for self-governments at the regional, county (the "powiat") and communal level. The financial sources for territorial selfgovernments activities obtained from the European Union planning perspective for 2014-2020, divided into particular activities, are presented in the compilation below.

Table 3. Financial sources for territorial self-government activities obtained from the EU means in the financial perspective 2014-2020. Source: [5].

\begin{tabular}{ll}
\hline $\begin{array}{c}\text { Field of } \\
\text { operation }\end{array}$ & \multicolumn{1}{c}{ Operations financed within the EU aid } \\
\hline $\begin{array}{l}\text { Technical } \\
\text { Infrastructure }\end{array}$ & $\begin{array}{l}\text { Territorial self-government unit can obtain EU funding for projects } \\
\text { connected with waste utilization or water and sewage facilities. } \\
\text { Communes can develop drinking water pipelines, sewage pipelines } \\
\text { or sewage treatment plants. }\end{array}$ \\
& $\begin{array}{l}\text { European Funds also support development of transport } \\
\text { Transport }\end{array}$ \\
& $\begin{array}{l}\text { infrastructure, roads and some accompanying elements of the } \\
\text { to be used on city transport, especially its ecological forms. For }\end{array}$ \\
& $\begin{array}{l}\text { instance, purchase of low-emission bus or tramway fleet can be } \\
\text { supported. }\end{array}$ \\
& $\begin{array}{l}\text { Self-governments can implement projects concerning } \\
\text { environmental education or preparation of urban planning }\end{array}$ \\
Natural &
\end{tabular}


protection documentation. There also appear funds for remediation or reclamation of the affected areas, enhancing or making green infrastructure or ecological corridors.

Energy Co-financing can also cover ventures supporting energy saving. production Self-governments can be granted financing for, e. g.: improved thermo-insulation of houses. In particular, buildings having institutional ownership (public company, local administration), but also the subsidies can support private home owners.

Information Electronic solutions are more and more common in administrative technologies procedures. Self-governments can get subsidies to develop electronic and IT solutions in their regional programmes. Thanks to such support the so-called public e-services can be developed.

Social Within regional programmes, self-government units can be given infrastructure support for construction, e.g. infrastructure in schools, kindergartens, hospitals, social care homes. However, financing for such purposes has not been planned for all regions (voivodships). Availability depends on a particular region.

Social Self-governments which operate within various social projects activation included in regional programmes are able to co-finance measures preventing unemployment by acting through local employment offices. Social welfare and family support centres try to obtain cofinancing of projects which activate people in difficult professional and social position.

Culture Apart from e-culture projects, self-governments and culture can also realise investment ventures. Particularly, much appreciation should be given to financing of ventures aimed at preserving cultural heritage and historical sites renovation

In conclusion, it needs to be stated that the analysis of financial means allocation made above shows two aspects: participation of the means in expenditure on current actions and property development ventures, and also the identification of the areas currently co-financed by the EU aid. In the period analysed (2010-2014), there can be observed a very high participation of the EU funding in some projects implemented by the territorial self-government units as far as current expenditure is concerned. Nevertheless, in this category of expenditure, the EU funding share was low, (below $2 \%$ ) in the total expenditure, because the EU projects have only a complementary character when referred to the core activity of the self-government. In case of property expenditure, the implemented projects received the EU financing at levels between $60 \%$ and $75 \%$. These projects made a considerable part of self-governmental investment, and therefore the participation of the EU funds in financing of all property expenditures was also at a high level. 


\section{Conclusions}

The paper analyses influence of the EU funds on regional development in Poland. Apart from description of the basic terms and interpretations concerning the categories of the local and regional development it has been indicated that the importance of the EU cohesion policies and the EU funding has been growing for territorial self-government units. By introducing the effects of the EU funds participation in regional and local development in Poland, the role of the EU funding has been stressed, including the problem of indebtedness as a side effect of such policies. The EU - funds are meant to be the tools to enable realization of the planned pro-growth ventures whose objective are: a steady economic development, increase of competitiveness of the regions and diminishing disproportions between them.

It must be stressed that, for the Polish self-governments, effective application of the EU funds is absolutely crucial. However, Self-governments should not be under pressure to use up the whole amount available, as it is possible to waste money in missed ventures, or the process can excessively burden the budget (repayment and interest on loans). The EU funds should only contribute into development and not into costly and meaningless indebtedness. Many factors indicate that the system of expenditure of the EU funds in Poland is disciplined by strict regulations and debt limits. Nonetheless, a bad choice of a UE-funded investment in the current period can block implementation of some necessary investment over the following years. Application of the EU funds can contribute into some improvement of pro-growth infrastructure, but through the repayment of liabilities connected with gathering the necessary own capital for the project, a problem of 1 maintaining the effects can arise (e.g. keeping in good condition the infrastructure only from the self-governments own budget).

In the summary, it should be stressed that self-governments in Poland have to avoid wrong decisions in undertaking and implementation of numerous tasks and should try to adjust to the actual social and economic needs. In this context, it is necessary for self-governments to be involved in the rational implementation of the cohesion policy guidelines, focusing on long - term approach towards development.

Strategic management based on regional and local budgets should largely be a result of strength of public structures involved in the cohesion policy. Smart management, starting from proper software applications, through implementation of particular projects and their evaluation, should be coordinated at the national and regional levels. Moreover, it seems necessary to set these actions into long-term arrangements having many interactions at all administrative levels. Such approach should positively impact economic development on the micro- and macro- levels. 


\section{References}

1. Arregui, J., Thomson, R.: Domestic adjustment costs, interdependence and dissent in the council of the European Union, European Journal of Political Research 53(4): 692-708, (2014), DOI:10.1111/1475-6765.12060.

2. Dinan, D.: Governance and institutional developments: in the shadow of the constitutional treaty, JCMS: Journal of Common Market Studies 44: 63-80, (2006), DOI:10.1111/j.1468-5965.2006.00645.x.

3. Domański, B.: Krytyka pojęcia rozwoju a studia regionalne, „Studia Regionalne i Lokalne", nr 2(16), (2004).

4. Filipiak, B.: Strategie finansowe jednostek samorządu terytorialnego, PWE, Warszawa, (2008).

5. Fundusze Europejskie dla jednostek samorządu terytorialnego, Ministerstwo Rozwoju

Regionalnego,http://www.funduszeeuropejskie.gov.pl/media/19717/ulotka_dla_jedno stek_samorzadu_terytorialnego.pdf [last accessed 01.09.2017].

6. Hołuj, A., Korecki, D.: Uwarunkowania rozwoju regionalnego w Polsce, „Zeszyty Naukowe Wyższej Szkoły Ekonomicznej w Bochni, (2008).

7. Informacja NIK, Realizacja zadań publicznych przez spółki tworzone przez jednostki samorządu terytorialnego. Informacja o wynikach kontroli NIK. Departament gospodarki, skarbu państwa i prywatyzacji. KGP-4101-002-00/2014. Nr ewid. 13/2014/p/14/019/KGP, NIK Warszawa, (2015).

8. Ofiarski, Z.: Subwencje i dotacje jednostek samorządu terytorialnego, Difin, Warszawa, (2002).

9. Ruśkowski, E.: Ogólne zasady wydatków JST. W: E. Ruśkowski, J. Salachna (red.), Finanse lokalne po akcesji, Warszawa: Wolters Kluwer Polska, (2007).

10. Standar, A.: Realizacja przedsięwzięć inwestycyjnych przez gminy - skala, zróżnicowanie i perspektywa, Problemy Zarządzania, vol. 15, nr 2 (67), cz. 1: 161 172 ISSN 1644-9584, Wydział Zarządzania UW, (2016) DOI 10.7172/16449584.67.9.

11. Swianiewicz, P.: Finanse samorządowe. Koncepcje, realizacja, polityki lokalne. Municypium, Warszawa, (2011).

12. Toshkov, D.D: The impact of the Eastern enlargement on the decision-making capacity of the European Union Journal of European Public Policy Vol. 24, Iss. 2, (2017), DOI:10.1080/13501763.2016.1264081.

13. Wieloletnie prognozy jednostek samorządu terytorialnego w Polsce w latach 20132016,http://www.mf.gov.pl/ministerstwo-finansow/dzialalnosc/finansepubliczne/budzety-jednostek-samorzadu-terytorialnego/informacje-i-zestawienia [last accessed 01.09.2017].

14. Local Data bank (the BDL) of the GUS (Central Statistical Office) https://bdl.stat.gov.pl/BDL/metadane [last accessed 01.09.2017]

15. Central Teleinformation System SL -2014, (Date of report printing: 2017/09/01, 07:12:24) 